\title{
Džihád v pojetí představitelů českých muslimů. Interpretační rozmanitost a její prríčiny
}

\author{
Karel Černý - Jiřina Stehlíková \\ DOI: 10.21104/CL.2021.2.02 \\ Perceptions of Jihad among Czech Muslim Community Leaders. \\ Interpretative Plurality and its Causes
}

\begin{abstract}
Abstrakt
The paper is based on interviews with Czech Muslim community leaders and focuses on the way they interpret the concept of jihad, how they think the concept should be implemented in action, and what factors shape their interpretations. It reveals two parallel understandings of the concept: a wider interpretation (i.e., the struggle to promote something good) and a narrow one (armed struggle). Three different typologies of jihad have been identified. With regard to the narrow definition of the concept, there is a consensus that jihad is legitimate in self-defence. Conversely, there is a tendency to reject the offensive jihad, but there is little consensus regarding the many conditions under which jihad can be declared and waged, especially as to the authority that can declare jihad or if it exists. The interpretative plurality is shaped by five factors, which relate to different authorities, ethical principles and audiences, different interpretations of Islamic history and contemporary political realities.
\end{abstract}

\section{Key words}

Islam, Muslims, Czech Republic, jihad, self-interpretation

\section{Acknowledgment}

Tento text vychází v rámci grantu GAČR (20-24833S) s názvem Př́padová studie blízkovýchodního uprchlictví: Iráčtí jezídé.

\section{Kontakt}

Mgr. Karel Černý, Ph.D., Katedra sociologie, Fakulta humanitních studií, Univerzita Karlova, Pátkova 5, 18200 Praha 8 - Libeň, Czech Republic; e-mail: karlos.cernoch@post.cz.

Mgr. Jiřina Stehlíková, Praha; e-mail: jirina.stehlikova@seznam.cz.

Jak citovat / How to cite

Černý, Karel - Stehlíková, Jiřina. 2021. Džihád v pojetí představitelů českých muslimů. Interpretační rozmanitost a její příčiny. Český lid 108, 151-174. https://doi.org/10.21104/CL.2021.2.02 


\section{Úvod. Islám v diaspoře a muslimské sebeinterpretace}

Muslimské organizace $u$ nás v minulosti vydaly brožuru či DVD věnované tematice džihádu, na toto téma také pořádaly expertně obsazenou konferenci. Kromě toho se jejich představitelé periodicky veřejně distancují od teroristických útoků páchaných ve jménu džihádu a koncept jsou nejpozději od 11. zárí 2001 nuceni zas a znovu diskutovat ve veřejných debatách s novináři a dalšími př́slušníky majority. V neposlední řadě se pak po tzv. arabském jaru objevilo několik případů muslimů žijících dlouhodobě v Česku, kteř́ sympatizovali nebo různými způsoby podpořili teroristické organizace etablující se na Blízkém východě. $\mathrm{Z}$ toho všeho lze nepř́ímo usuzovat, že je pro představitele tuzemských muslimských organizací problematika džihádu natolik důležitá, že ji nemohou ignorovat. Cíl studie je proto trojí. Zjistit, jak představitelé českých muslimů interpretují koncept džihádu, diskutovat, jaké mohou mít tyto interpretace konsekvence pro oblast jednání, a především identifikovat faktory, které ovlivňují interpretační pluralitu. Představitelé muslimů vstupují do veřejného prostoru a zároveň jsou součástí té menšiny českých muslimů, kteří se sdružují ve formálních organizacích. Lze tedy předpokládat, že své interpretace džihádu nenabízejí jen směrem ven, do prostředí většinové společnosti, ale také směrem dovnitř, do prostředí muslimských komunit. Jakkoliv nelze přeceňovat míru jejich vlivu na ostatní muslimy: muslimské náboženské pole v Česku je velmi fragmentované (Kropáček 2012), mezi českými muslimy převládají privatizované a individualizované verze religiozity a většina sdružování probíhá na bázi sdílené etnicity, nikoliv sdílené zbožnosti, přičemž islámské autority v Česku stejně jako ve světě erodují (Topinka 2016).

Blízkovýchodní studia na základě rozboru islámských textů zpracovala, jak Korán, sunna a jednotlivé právní školy (mazhab) chápou koncept džihádu a jak se uplatnil ve starších či novodobých dějinách. Tato akademická literatura také ukazuje, jaké typy džihádu se v islámské tradici postupně vyprofilovaly: džihád srdcem, jazykem, rukou či mečem, v jehož rámci lze dále rozlišit džihád obranný a útočný, případně džihád chápaný jako kolektivní či individuální povinnost (srov. Kropáček 2007: 114-116; Mendel 2010: 23-86). Další bohatá literatura reflektuje, jak inovativně s konceptem džihádu - především džihádu mečem - pracují ideologové moderních islámských politických hnutí, včetně extremistických (srov. Kepel 2002; 2008; Pape 2006; Kurzman 2011). Avšak tato studie neodkrývá, co o džihádu ř́kají texty politických aktivistů a extrémistů nebo samotný Korán a prorocká tradice (sunna). Naopak mapuje dosavadní bílé místo v podobě otázky, co říkají muslimové o tom, co na adresu džihádu ř́ká Korán a další islámské texty. Mimo jiné se tím studie hlásí ke stále aktuální kritice 
Anouara Abdel-Maleka (1963) a Edwarda Saida (2006), že pro porozumění muslimským společenstvům je kromě textů především zapotřebí studovat samotné muslimy. Vychází přitom z předpokladu, že čeští muslimové jsou součástí globálního trendu, kdy si, stejně jako ostatní obyvatelé Evropy kladou otázku, kdo je a není správný muslim, co je a není islámské, jak korektně chápat islámské právo šaría či právě džihád. Naléhavost těchto otázek je pak dvojnásobná v menšinových muslimských diasporách v Evropě, kde je islámská identita spíše věcí vyjednávání a volby než pasivního a nereflektovaného přijímání náboženství rodičů ve většinově muslimských společnostech $\mathrm{s}$ tlakem na konformitu. Identita menšiny se dále definuje skrze vymezování se vůči sekulární postkřestanské většině, která navíc na menšinu vytvárí sebereflexivní tlak kladením otázek, co to znamená být muslimem, co je islám a džihád. Islámské náboženství definované konečnou množinou kodifikovaných posvátných textů se tak nemění, ale proměňuje se religiozita, tedy vztah muslimů k islámu, ostatním muslimům a nemuslimům (Roy 2006). Proto se zřejmě proměňuje i chápání samotného džihádu, přičemž ambicí studie pak je aktuální transformaci reflektovat.

Tuto muslimskou sebeinterpretaci přitom chápeme jako kontinuální proces o třech úrovních, jak ho konceptualizuje Maxim Rodinson (2015: 151-155). Tyto tři roviny stručně charakterizoval Edward Said (1981: 55) takto: „Nemůže existovat islám bez Koránu; ale ani naopak nemůže Korán existovat bez muslimů, kteř́ by ho četli a interpretovali a to se poté pokoušeli promítnout do institucí a sociálních realit." První úroveň se týká Koránu a prorocké tradice, tedy posvátných textů, ke kterým se všichni muslimové vztahují. Tato úroveň odráží to, jak je koncept džihádu př́tomen v posvátných textech. Druhá úroveň se týká „permanentní revoluce“ v islámu, tedy vzájemně konfliktních interpretací těchto posvátných textů provázených nejen střety mezi ortodoxií a heterodoxií, ale i spory na půdorysu ortodoxie samotné, kdy se periodicky objevují snahy o návrat ke kořenům $\mathrm{v}$ podobě posvátných textů a praxe raných muslimů. Dané interpretace se navíc proměňují v čase a prostoru, vždy ale záleží na tom, jaký nebo čí islám máme na mysli. Jedná se tedy pokaždé o islám s př́ivlastkem. Tato úroveň tak odráží to, jak džihád chápou, jakkoliv třeba rozporně, konfliktně a proměnlivě, samotní muslimové.

Třetí úroveň se týká toho, že nejen jednotlivé interpretace islámu, ale i jedna a táž jeho interpretace může lidské jednání formovat různým a v čase proměnlivým způsobem. Nikdy ale není hlavním, a už vůbec ne jediným faktorem formujícím jednání muslimů. Má se kupř́íkladu za to, že islám př́liš neovlivnil rozmanité podoby hospodářského života jednotlivých muslimských společností, které formovaly spíše geografické podmínky. Jen o něco větší vliv měl na politické jednání a společenské uspořádání, které se 
mezi jednotlivými muslimskými společnostmi a epochami lišilo a odvíjelo se spíše od zájmů politických elit než od islámského práva. Nejvíce patrně islám ovlivnil dějiny myšlení, ačkoliv i zde se prolínal s vlivem předislámských tradic, včetně antické filozofie (srov. Geertz 1968; Hourani 1976). Tato úroveň odráží rozmanité představy ohledně toho, jakým způsobem by se měly dané interpretace džihádu uvádět do praxe, pokud vůbec. Jinými slovy, dokonce i tentýž koncept džihádu se může do praxe překlápět různými způsoby, přičemž daná interpretace džihádu zřejmě nebude hlavním, a už vůbec ne jediným faktorem orientujícím př́ípadné jednání.

Třetí úroveň analyzující relativně volný vztah mezi jednotlivými interpretacemi islámu a jimi formovanými vzorci jednání organicky doplníme o tezi Maxe Webera o nepř́močarém vztahu mezi nábožensky informovanými postoji ke světu, náboženskou etikou a jednáním, kterému propůjčují smysl právě odkazy na náboženskou tradici. Komparativní zjištění Maxe Webera hovoří nejen o tom, že různé postoje ke světu ústí v různou etiku a jednání. Ale také o tom, že dokonce tytéž základní postoje ke světu mohou generovat různé etiky, a jednání tak orientovat různým směrem. Kupř́kladu základní postoj odmítající svět jako něco podřadného, mravně degenerovaného, či dokonce ontologicky nicotného může ústit v aktivisticky orientované jednání snažící se zkažený pozemský svět napravit (radikální protestantismus), nebo naopak v pasivně orientované jednání obracející se do lidského nitra a pokoušející se z vazby na korumpující pozemský svět uniknout (raný buddhismus) (srov. Arnason 2003: 86-104). Jinými slovy, potenciálně rozmanité implikace konceptu džihádu pro oblast jednání nevyplývají pouze z rozdílných interpretací náboženských textů, ale stejně tak z nábožensky informované interpretace reality, v níž si muslimové čtou úplně stejně jako v samotných textech a kterou pak také mohou vykládat dosti různě.

Mark Juergensmeyer (2007) na extrémním př́kladu nejen islámského terorismu ukázal, že se teroristé od ostatních př́islušníků téže náboženské tradice př́liš neliší v interpretacích sdílených posvátných textů, jakkoliv u nich lze vystopovat specifickou interpretační tradici jdoucí k Sajjidu Qutbovi nebo Muhammadu ibn Abd al-Wahhábovi (srov. Čejka 2020). Teroristé se totiž s ostatními rozcházejí především v tom, jak skrze optiku tzv. kosmické války čtou svět, ve kterém žijí, případně i dějiny, které prožili jejich předci a na jejichž mučedníky padlé ve jménu dobra a na tradici odporu proti zlu navazují. Nábožensky informovaná optika jim umožňuje vidět svět jako místo, kde na všech úrovních - od nitra jedinců přes společnost až po vesmír - zuř́i nekompromisní střet mezi silami zla a dábla a silami dobra a Boha, kterým by měl každý věřící přispěchat na pomoc, přičemž teroristy frustruje, že jejich „velkou pravdu“ o stavu světa ostatní souvěrci nenaznali nebo naznali, ale nechává je to přesto chladnými. Také v našem 
výzkumu se proto zaměříme i na to, jak informanti interpretují svět a jaké konsekvence to má pro jejich představy o tom, zda a jak praktikovat džihád.

\section{Metodologie výzkumu}

Sběr dat probíhal v roce 2015 a poté opět v letech 2019 až 2021. Formou podrobných polo-strukturovaných rozhovorů byli dotazováni představitelé českých muslimů ze dvou hlavních muslimských obcí v Praze a Brně, at již migračního původu, či konvertité, kteří reprezentují hlavní muslimské organizace hlásící se k sunnitské ortodoxii, jež se v České republice po roce 1989 etablovaly: Ústředí Muslimských obcí a Muslimská obec v Praze a v Brně, Muslimská unie, Liga českých muslimů, Islámské centrum Alfirdaus. Výzkum je založen na dostupném vzorku devíti informantů, přičemž sběr dat byl ukončen v momentě, kdy došlo k tzv. teoretické saturaci vzorkem; výpovědi dalších informantů se začaly opakovat a věcně nepřinášely nic nového. Vychází z kvalitativní metodologie pracující s velkým množstvím dat sebraných od malého množství informantů. Ambicí kvalitativního výzkumu nebylo zobecňovat výsledky na populaci všech muslimů žijících v České republice, ale prozkoumat pojetí džihádu v jádrových skupinách organizovaných českých muslimů. Jinými slovy, výzkum usiluje o teoretické zobecnění vzhledem $\mathrm{k}$ budované akademické reflexi pojetí konceptu džihádu mezi reprezentanty českých muslimských organizací (srov. Hendl 2008). Mezi informanty zpovídané během roku 2015 patřil Vladimír Sáňka (geolog, konvertita, dlouhodobý předseda Muslimské obce Praha), Samer Shehadeh (překladatel, absolvent Islámské univerzity v Medíně, bývalý imám Islámského centra v Praze palestinského původu, toho času ve výkonu trestu za účast na teroristické skupině),${ }^{1}$ Muneeb Alrawi (inženýr, předseda Ústředí muslimských obcí České republiky původem z Iráku), Emir Omić (obchodník, bývalý imám Islámského centra v Praze původem z Bosny a Hercegoviny) a Muhammad Abbás (inženýr architektury, ředitel Muslimské unie původem ze Súdánu). Během let 2019 až 2021 byly realizovány rozhovory s Lukášem Alím Větrovcem (akademik, konvertita, provozovatel serveru e-islam.cz a facebookové stránky Islámské nauky, v minulosti aktivní v Muslimské obci Brno), Petrem Pelikánem (arabista a diplomat, konvertita, spoluzakladatel Ligy českých muslimů), Baderem Eknaifithem (obchodník, vedoucí islámského centra a jednatel společnosti Alfirdaus původem z Kuvajtu) a Leonidem Kušnarenkem (advokát, kon-

1 Srovnávací analýza pojetí džihádu a širšího světonázoru Samera Shehadeha s cílem porozumět jeho podpoře syrských militantních organizací, jež figurují na oficiálních západních seznamech teroristických organizací - je předmětem jiné studie. 
vertita pocházející z Ukrajiny, zástupce českých muslimů v Evropském muslimském fóru). Získaná data pokládáme za unikátní už jen z toho důvodu, že jejich sběr proběhl navzdory rostoucí nedůvěře mezi muslimy a majoritní společností. Ochotu informantů participovat na výzkumu s citlivou problematikou i ve vyhrocené atmosféře tzv. uprchlické krize dokonce pokládáme - jakkoliv jde o tvrzení jdoucí nad rámec provedeného výzkumu - za jistý doklad jejich solidní integrace. Přestože se jedná o muslimy reprezentující oficiální muslimské organizace, kteří pod svým jménem islám v České republice dlouhodobě zosobňují, rozhodli se nakonec autoři v tomto prŕpadě uvádět jejich výroky anonymně.

Polostrukturované rozhovory vždy obsahovaly následující okruhy otázek, bývaly však doplněny o otázky reagující na konkrétní odpovědi: stručné vysvětlení pojmu džihád, charakteristický př́klad džihádu z minulosti a současnosti, verš z Koránu či př́běh ze sunny podporující interpretační stanovisko informanta, relevance typologií džihádu a př́padně, jaký typ lze chápat jako nejhodnotnější před Bohem, zda a za jakých podmínek lze vést tzv. džihád mečem, $\mathrm{k}$ jaké autoritě, směru či právní škole se informant ve svém pojetí džihádu hlásí. Všechny rozhovory byly vedeny v českém jazyce a po stylistické stránce nebyly upravovány. Analýza rozhovorů proběhla s pomocí metody zakotvené teorie, konkrétně tzv. otevřeného kódování. K tomu docházelo skrze opakované pročítání rozhovorů, což umožnilo základní tematické rozkrytí odpovědí na př́slušné otázky. Identifikace základních typů odpovědí (např. distancování se od útočného džihádu, tendence k etymologickému rozboru významů slova džihád) poskytla první relativně ucelený náhled na data. Snahou bylo odhalit, kde mezi informanty krystalizuje konsenzus a kde naopak postoje zůstávají polarizované přes sbírání stále dalších rozhovorů. Podobně identifikace základních typů odpovědí stimulovala i jejich uspořádávání do skupin podle obsahové podobnosti či rozdílnosti (např. četné podmínky pro vyhlášení nebo vedení džihádu mečem). To ústilo v postupnou identifikaci abstraktnějších pojmů a obecnějších zastřešujících kategorií seskupujících vzájemně si blízké odpovědi (např. úzké a široké vymezení džihádu) (srov. Strauss a Corbinová 1999).

Pokusme se kriticky upozornit na to, v jaké situaci k interpretaci džihádu ze strany informantů docházelo, a jaké tedy mohou být př́činy možného - at již vědomého, či nevědomého - zkreslení či autocenzury z jejich strany (podle Said 1981: 154-160). Předně zohledněme, $k d o$ je interpretem: mužští představitelé formálně organizovaných českých muslimů hlásící se k sunnitské ortodoxii a snažící se směrem k majoritě, českému státu či zahraničním donorům prezentovat jako představitelé většinově neorganizovaných českých muslimů, kteří ovšem mnohdy nestojí o to, aby je kdokoliv 
zastupoval a hovořil jejich jménem (srov. Topinka 2016). Dále pojmenujme, že interpretace je primárně určena nemuslimskému akademickému publi$k u$, skrze něž informanti nepřímo promlouvají i k většinové společnosti či představitelům státu, včetně činovníků bezpečnostních složek. Účelem interpretace pak může být snaha prezentovat islám v co nejlepším světle a s misionářským zaujetím širrit povědomí o tomto náboženství ve většinové společnosti (dawa), distancovat se od extremismu a odvrátit tak podezření ze sympatií $\mathrm{k}$ islamistickým militantům, formálně vykázat dobrou vůli v podobě mezináboženského dialogu nebo pragmaticky budovat sociální kapitál se spřízněnými akademiky.

Klíčová je i reflexe historického a politického kontextu, ve kterém se interpretace rodí. Charakterizuje ho nedůvěra muslimů vůči českému státu daná zamítnutím žádosti Ústředí muslimských obcí o uznání islámu ze strany státu, a tedy o zrovnoprávnění islámu s judaismem a křestanstvím (srov. Mendel a kol. 2008). Nedůvěru dále přiživuje monitoring formálně organizovaných muslimů tajnými službami nebo policejní zásah během páteční bohoslužby v Praze (2014) spojený s obžalobou jednoho z informantů (zproštěn ve všech bodech obžaloby). Česká republika je dále spojencem Státu Izrael a po boku západních spojenců se účastní vojenských intervencí na širším Blízkém východě (Afghánistán, Irák, Mali), které část informantů hodnotí negativně, leč volí opatrné formulace odpovědí. Druhá vlna rozhovorů navíc proběhla poté, co byl další z informantů pravomocně odsouzen za podporu teroristické skupiny působící v Sýrii. A navíc také po tzv. uprchlické krizi (2015-2016) spojené se vzestupem Islámského státu a vlnou teroristických útoků v Evropě, kdy v majoritě rostl strach z islámu a následně se rozmohly protimuslimské útoky z nenávisti, které naopak zasely strach mezi samotnými muslimy (srov. Ostřanský a kol. 2017). Nakonec reflektujme, v jaké relaci jsou dané interpretace džihádu k ostatním interpretům téhož fenoménu. Lze očekávat jistou apologetiku a vymezení se vůči tomu, jak negativně džihád interpretují teroristé, islamofobové a média, čemuž nasvědčuje polemický či a priori defenzivní charakter některých rozhovorů. Potenciálně se také informanti - aspirující na zástupce českých muslimů a reprezentující vzájemně si konkurenční organizace - mohou vymezovat i proti sobě navzájem, což však nebylo př́liš zřetelné.

\section{Oscilace mezi širokým a úzkým pojetím džihádu}

Vykrystalizovaly dvě základní interpretace džihádu, široké a úzké. Primární způsob interpretace pracuje s etymologickým rozborem. Informanti tak vysvětlují význam arabského slova džihád s tím, že se jedná o „vyvíjení úsilíi, „snažení se“, „vydání ze sebe maxima“, „porvání se s obtíží“, „boj 
ve všech konotacích toho slova“. V této souvislosti pak konstatují, že koncept džihádu má široký význam. Jak se vyjádřil dlouholetý reprezentant pražských muslimů: „Slovo tedy má velmi široký význam - snažit se v nějaké dobré a bohulibé činnosti. "Vejde se pod něj škála každodenních skutků: boj s chtíčem a pokušením, péče o stárnoucí rodiče, snaha uživit rodinu, úsilí o dobré výsledky ve studiu, snaha vědce učinit objev, přemáhání spánku kvůli bohulibému skutku, pomoc lidem v nouzi. Jak ř́ká mladý konvertita: „Bliží se pưlnoc, jsme unavení a pijeme dalši kafe, přesto se na dokončení rozhovoru nerykašleme. I to je džihád. "Podobně informanti v širokém pojetí uvádějí skutky spjaté s posilováním víry své i druhých: putování do Mekky, vstávání na ranní modlitbu, snahu argumenty opravit mylné pojetí islámu u jiných muslimů, trpělivé vysvětlování islámu nevěřícím, čelení české xenofobii. Podle mladého konvertity nabízí život menšinových muslimů ve většinově sekulární a vưči islámu nepřátelské české společnosti př́ležitost pro džihád. Ten bojují ti, kteř́ vzdorují tlaku ze strany většiny, jdou se svou kůží na trh a jako alternativu přitom nabízejí islám. Džihádem tak je „neudělat islámu zlé jméno" a "nést jeho vztyčený prapor" navzdory islamofobii. Džihád prý takto vedli v Mekce první muslimové, když se ostatním snažili přes ústrky nenásilně doručit boží zvěst, jak uvádí starší obchodník: „Jejich džihádem byla trpělivost. "Podobně dnes podle něj vedou svůj džihád čínští Ujgurové, barmští Rohingyové nebo běžní Palestinci, když se snaží trpělivě přečkat útlak ze strany nespravedlivé vlády, islamofobní většiny či okupační armády.

Tábor hlásící se k širokému pojetí tendoval k oddělení konceptu džihádu od násilí. Defenzioní postoj se ale - jen v různé míře - projevil u všech informantů. Ti předjímali existenci negativních představ ohledně džihádu ve většinové společnosti, a proto preventivně zdůrazňovali, že pojetí džihádu nelze zužovat na ozbrojený boj. Typicky se vyjádřil starší bývalý imám:

„Je mi jasné, že dneska, obzvláštè v nemuslimském světě, je slovo džihád chápáno pouze jako válečný termín, což je daleko od skutečnosti a daleko od islámské tradice. Ve velké míre $k$ tomu přispívaji i politická, často militantní hnutí v muslimském světè, která v̌̌echno, co se dá, zneužívají ke svému prospěchu."

Podobně s poukazem na prorockou tradici (sunna) argumentuje dlouhodobý reprezentant českých muslimů: „A výroky Proroka, když ř ekne mu tedy (mladíkovi toužícímu připojit se $\mathrm{k}$ vojenskému tažení, pozn. K. Č.): tvưj džihád je starat se o rodiče, zưstaň s rodiči. Takže to je mi jasné, že džihád neznamená vytasit meč a vést ten boj."

Vykrystalizoval ovšem i úzký pohled, který džihád vidí jako ozbrojený boj, jakkoliv spíše obranný. Zde si informanti pomáhali historickými př́- 
klady. V současnosti ho pak někdy dávali do souvislosti s odporem proti okupaci nebo nespravedlivé vládě. Arabský inženýr vysvětluje obranný charakter džihádu tím, že víru nelze šírit silou, protože ta může být přijata jen upř́mně a bez donucení:

„Tak proní věc, džihád v islámu - jeho smysl je na obranu, protože islám zakazuje, aby někdo byl donucen ve víre, smyslem je, aby si sám vybral. Hodně veršu v Koránu říká, že život je volba. Že člověk vždycky má volbu mezi dobrem a zlem a že smysl každého je, aby si člověk sám vybral a nebyl donucen."

Charakteristická je ovšem oscilace mezi úzkým a širokým vymezením džihádu spjatá s defenzivním postojem, kdy se často ten samý informant, více či méně konzistentně, hlásí k oběma pojetím. Tento inženýr kupř́kladu s charakteristickým odkazem na etymologii připomíná možnost širšího chápání konceptu, které není spjato s násilím: „Ale v arabštině se slovo džihád nepoužívá jenom na válku, také se používá na úsilí, může být džihád pro někoho studovat, dokončit vysokou školu. "Mladý konvertita zase pokládá za charakteristické historické př́klady džihádu ty spjaté s boji první generace muslimů při širření víry. Ale za džihád pokládá i otevřené praktikování víry v prostředí, jež muslimům není nakloněno, nebo sociální reformy.

Disentní pohled nabízí znalec sunny, podle kterého jde vždy o ozbrojený boj: „Džihád je jedna z povinností muslimů a je to ozbrojený boj, nebo podpora ozbrojeného boje, za islámskou entitu, který má určitá pravidla a na který se váže rada podrobnějš́ch ustanovení. "Ve významu „usilovat" lze podle něj koncept chápat jen v kontextu arabského textu Bible. V Koránu se naopak podstatné jméno džihád, respektive sloveso „džihádovati“ primárně pojí s bojem a v tomto významu je také až na výjimky ve standardním českém převodu Koránu z pera Ivana Hrbka překládán. Podobně také další odvozená slova se významově pojí s bojem: kupř́kladu „mudžáhid“ není chápán jako bojovník s vlastními slabostmi, ale s nepřáteli; také proto bývá zvykem v závěru páteční modlitby prosit Boha o požehnání „bratrưm mudžáhidům, tam kde se vedou boje“. Klíčový argument ale pracuje s prorockou tradicí (sunna):

„Ve většině tradic, $k$ de se vyskytuje podstatnéjméno džihád nebo sloveso džáhada, vésti džihád, tak je to ve spojení s ozbrojeným bojem nebo jeho podporou. Pouze určitá část tradic, kteréjsou zjevně pozdějš́ho původu, určité skutky prirovnává $k$ džihádu svým významem, což je podle mého soudu klasický staroarabský řečnický obrat. Takže se zde neř́ká, toto je džihád, ale že takové činy jsou jako džihád, jsou natolik záslužné. Je to určitá hyperbola." 
Když prý prorocká tradice formuluje ustanovení týkající se džihádu, je zřejmé, že souvisejí s válkou: kdo a za jakých okolností může být z účasti na džihádu zproštěn; detailní pravidla pro rozdělování kořisti; možnost využít náboženskou daň (zakát) na vedení džihádu. Jak uzavírá: „Takorých detaili je prŕliš mnoho na to, abych mohl prijmout koncepci velkého džihádu, který je ten mírumiloony."

\section{Široké pojetí. Konkurenční typologie džihádu a jejich hierarchie}

Informanti se k typologii džihádu stavěli vesměs odtažitě. Vadilo jim, že žádná z nich není tak obsáhlá, aby pojala rozmanitost jeho významů. Vesměs ale souhlasili, že je možná. Ve výsledku vykrystalizovaly tři typologie, jež je možné rozvíjet na půdorysu širokého pojetí džihádu. Starší obchodník, s odkazem na oblíbený hadís, zmiňuje základní dichotomii: „Když se Prorok se soými druhy vrátil z boje, řekl, že to byl malý džihád, ale ted'je všechny čeká džihád velký, boj se sebou samými, se špatnými vlastnostmi a se zlem $v$ dušich. "Rozlišil tak menší džihád mečem a tzv. velký džihád srdcem. Takto dichotomicky uvažuje též starší konvertita, pro kterého je velký džihád nadřazený malému, který v dnešním světě s despektem odmítá: „Dodržovat každodenně a celý život spoustu drobností je složitějš́ než odjet někam na Východ, vzít kalašnikov a nechat se zabít v boji. To je až moc jednoduchý."

Druhá typologie se odvíjí od islámského principu přikazování ctnostného a zakazování zavrženíhodného a spíše než typy džihádu vymezuje jeho sestupné fáze. Podle mladš́ho bývalého imáma je lze odvodit od otázky „jak může člověk bojovat proti zlu?" Informanti se zde odvolávají na hadís Proroka Muhammada, který požadoval, aby se muslimové zasazovali o potírání zavrženíhodného jednání. Pokud mohou a mají k tomu oprávnění a schopnost, tak rukou, tedy fyzickým donucením. Pokud nemohou, tak alespoň slovním odsouzením. A pokud ani verbální vystoupení proti zlu není možné, pak ho mají odsoudit v srdci. Jak vysvětluje dlouhodobý reprezentant českých muslimů: „Vidíte někoho, jak okrádá pány na zastávce. A ted' zvážíte: pokud ho můžete chytnout, tak ho chytněte. Pokud se bojíte, tak aspoň budete kričet. (...) Když ne, tak aspoň to odsoudíte v srdci. "Tentýž princip pak aplikuje arabský inženýr na ozbrojený džihád: „Ano, to je podle toho, jak člověk mủže. (...) Bud' můžeš, máš možnost, jste člen v armádě. Nebo může se stát, že jste civilista, který ani neumí používat zbraň a tím pádem aspoň pomáhá jinými způsoby. Podle jeho možností. Bud'pomocí peněz, nebo slovy, nebo nakonec i modlitba. "Avšak starší obchodník pokládá islámský princip přikazování ctnostného a bránění zavrženíhodnému za autentický, protože vychází ze spolehlivého hadísu, ale s džihádem prý nesouvisí: „Prorok skutečně ř́kal, když děláš něco špatně, musís to opravit, rukou, jazykem nebo srdcem. Kdyžjste policista, můžete špatnost 
napravit rukou, když novinář nebo právník, tak jazykem. A když obyčejný člověk a nemáte jiné možnosti, tak srdcem. Ale to vůbec není džihád."

Stojí nicméně za povšimnutí, že část muslimů chápe obranu svých životů, rodin a majetků proti agresi v běžné každodennosti právě jako džihád rukou. Ale zároveň také jako ústavně zaručené právo na sebeobranu. Takto uvažuje kupř́íkladu starší konvertita, který v reakci na teroristické útoky v mešitách ve městě Christchurch na Novém Zélandu (březen 2019) české muslimy veřejně vyzval, aby si pořídili zbrojní průkazy. Šlo prý o výsledek pocitu, že je tlak a hrozba ze strany majority již př́liš velká a muslimové tak musejí uplatnit právo na sebeobranu: „Cítil jsem nutnost se $k$ tomu vyjádrìt. Četl jsem komentáre na internetu a ani jeden neoyjádřil s mrtoými muslimy soustrast. Naopak byla jasná latentní podpora dalšího zabíjení muslimů. "Informant tak pocitoval bezprostřední ohrožení: „Proto jsem se zachoval, jak jsem se zachoval. Udělal jsem jako občan České republiky správnou věc a nemám se za co stydèt. I kdyžjsem za to pak zaplatil."

Konkurenční typologie předpokládá čtyři typy džihádu: srdcem, jazykem, rukou a mečem. Tuto typologii systematicky uvedli jen dva informanti, jakkoliv byla ve fragmentech př́tomná i u dalších. Jak uvádí dlouholetý představitel pražských muslimů:

„Džihád srdcem je snaha o čistotu úmyslu, o vnitřní sebezdokonalování, o co nejsprávnèjš́ rozhodování, vyhýbání se špatnostem. Džihád jazykem je snaha o to mluvit správně, nebo raději mlčet. Řikat pravdu, i kdyby to bylo proti mým zájmưm. (...) Džihád rukou je předevš́m pomoc potřebným lidem. A to nejen když jim dám jídlo nebo peníze, ale také když pomůžu zař́dit jejich záležitosti. Džihád bojem je sebeobrana a ochrana rodiny, majetku, vlasti."

Pojetí džihádu pracující s představou jeho typů či stupňů implikuje jejich hierarchii. Jaký typ džihádu je před Bohem nejhodnotnější? Ani zde nepanuje shoda, informanti jsou navíc ve svých soudech inkonzistentní. Zcela disentní pohled nabízí znalec sunny, který se hlásí jen k úzkému pojetí autentického džihádu. Výkladům různých typů džihádu nedůvěřuje, protože se zakládají na jediné prorocké tradici rozlišující malý a velký džihád. Také podle staršího obchodníka podrobnějším typologiím džihádu chybí řádná opora v Koránu a hadísech.

\section{Úzké pojetí: Útočný a obranný džihád mečem}

Panuje jen obecný konsenzus ohledně džihádu mečem. Existuje tendence preventivně zdůrazňovat, že koncept nelze zužovat na násilí. Jak se vyjádřil 
starší bývalý imám: „Pripouštím, že džihád může nabýt i formu ozbrojeného boje. Omezovat džihád na válku a boj by ale byl zločin vưči islámskému náboženství." Př́tomna je i související defenzivní tendence zdůrazňovat, že islám je mírumilovné náboženství. Avšak informanti se shodují, že džihád mečem je přípustný v sebeobraně. Naopak se často distancují od útočného džihádu, zejména s cílem šírit víru. Slabý konsenzus se týká podmínek, za jakých lze džihád vést, a také toho, zda ho mohou vést jen státy, nebo i nestátní aktéri a jednotlivci. Polarizace názorů se pak týká toho, jaká autorita ho může vyhlásit a zda dnes taková autorita vůbec existuje.

Shoda panuje $\mathrm{v}$ tom, že je džihád mečem ospravedlnitelný v případě $s e-$ beobrany. Tuto konsenzuální pozici formuluje letitý představitel pražských muslimů takto: „Džihád bojem je sebeobrana a ochrana rodiny, majetku, vlasti. Korán takový boj povoluje. " Tezi o sebeobranném charakteru džihádu tento informant a další nejčastěji obhajují následujícím veršem Koránu: „A bojujte na stezce Boži proti těm, kdož bojují proti vám, avšak nečiñte bezpráví, nebot'Bưh nemiluje ty, kdož se bezpráví dopouštějí. "Jedná se o první verš Koránu, kterým Bůh muslimům povolil sáhnout $\mathrm{k}$ násilí. Také druhý nejčastěji citovaný verš Koránu chápe džihád mečem jako sebeobranu proti agresi. Verš cituje představitel pražských muslimů takto: „ঙi, proti nimžje vedena válka, mají dovoleno bránit se, nebot'se jim děje kř̀ivda - a Bưh je jim věru pomocníkem, těm, kdož byli bezprávně vyhnáni ze svých domovư jedině proto, že ríḱli: ,Pánem naším je Bưh!"“

Neexistuje ale shoda, za jakých podmínek lze obranný džihád vyhlásit a zda jde o koncept relevantní na úrovni mezistátních vztahů, s čímž většina souhlasí, nebo ho lze rozšririit na odpor proti vojenské okupaci či utlačivé vládě, a tedy ho mohou vést i nestátní aktéri reprezentující okupovanou či utlačovanou společnost, což je menšinový názor. Informanti ale v souvislosti s džihádem primárně uvažují o mezinárodních konfliktech. Zpravidla hovoří o právu napadených zemí bránit se agresi. Jak se typicky vyjádřil letitý představitel pražských muslimů: „Pokud je muslimská země napadena a musí se bránit proti vnějši agresi, je podle islámu možné použít sílu na obranu životio, majetku a muslimského území. "Informanti zmiňují univerzálnost práva států a národů na sebeobranu, islámské právo tedy nevybočuje z obecných pravidel mezinárodních vztahů. Podle arabského inženýra sama existence armády prakticky v každém státě implikuje možnost daného státu bránit se. Dlouhodobý reprezentant českých muslimů zase tvrdí, že Evropané bojující za druhé světové války proti nacismu nevedli nic jiného než džihád s cílem zabránit zlu, jakkoliv tomu tak neř́kali. Přitom zdůrazňuje další podmínku pro vedení džihádu, jíž je vyčerpání všech možností nenásilného urovnání konfliktu: „Tak jak Hitlera nešlo zastavit. Co zbylo tedy Evropanưm? Bojovat. Protože kdyby bývali zůstali mlčet, tak by je podmanil. Takže džihád vlastnè vedou všichni - muslim, nemuslim. A kterýkoliv z nich ho vede, tak on dèlá to správnè, kdyžje potřeba." 
Informanti uvádějí plejádu dalších podmínek pro vyhlášení džihádu. Shodují se, že je jich mnoho. Nikoliv na konkrétním výčtu, jakkoliv zde může být na vině omezený formát rozhovoru. Objevuje se např́íklad podmínka přiměřenosti reakce, jež by měla být úměrná síle agrese nepř́tele. Podobně starší obchodník jako podmínku stanovuje šanci ve válce vůbec vyhrát. Jít do předem prohrané konfrontace není džihád: „Když někdo př̀jde se stíhačkou F-16 a druhý proti němu jde na koni a myslí si, že dělá džihád." Kromě toho je arabským inženýrem a mladším bývalým imámem rozsáhle diskutován související princip: oběti džihádu jsou ospravedlnitelné pouze potud, pokud zabrání ještě většímu krveprolití. Jinak nikoliv. Tento pragmatický kalkul arabský inženýr zdůvodňuje islámským principem, podle něhož člověk nemá jednat tak, aby došlo ke zhoršení stávajícího stavu: „Kdyby ten boj vedl k něčemu hoř̌̌m u, než co je ve skutečnosti, vedl víc $k$ destrukci, $k$ větš́m zabití lidí, tak radši, aby se neválčilo. To je otázka, $k$ čemu to vede, jestli to zastaví zlo a destrukci, tak je to dobrý. Jestli to nezastaví, tak radši ne. "Dle mladšího bývalého imáma je v Sýrii proléváno daleko více krve, než by bylo prolito, pokud by se hned na začátku občanské války proti režimu rázně zakročilo: „Kdyby byl aplikován (džihád mečem, pozn. K. Č.), tak by nebylo dovoleno tèmto vládám nebo teroristickým organizacím, aby páchaly všechny tyto masakry, a národ by byl ochráněn. "Stojí za povšimnutí, že nejen zde se dostáváme do sféry interpretace reality, nikoliv islámských textů. Mladý konvertita pak tutéž realitu interpretuje opačně, když tvrdí, že syrská opozice rozsah krveprolévání vystupňovala až k chaosu, a její odpor $\mathrm{k}$ diktatuře tak nepředstavuje legitimní džihád. Starší konvertita do diskuse přispívá další podmínkou: nejde o boj, který muslimy rozděluje a vede ke vzájemnému zabíjení muslimů. Válku proti syrské diktatuře tak vidí jako zavrženíhodný rozkol (fitna), protože tam „válčí muslimové proti muslimům, v tom já džihád fakt nevidím. Spíse si myslím, že za to půjdou do pekla." Přiznává přitom, že „s velkým údivem sleduji, co se děje na Východě. Opět se tedy spíše než k interpretaci náboženství dostává k interpretaci politické reality. A apeluje, aby se čeští muslimové od konfliktů na Blízkém východě distancovali, nepocitovali povinnost angažovat se v tamním dění. Namísto toho nabádá držet se stranou od konfliktního regionu, pečovat o svou víru, dělat dobré skutky a starat se o rodinu: „V prípadě, že vidiš fitnu, velký nepokoj ve světě i mezi muslimy, máš podle hadísů Proroka odejít do jeskyně a modlit se."

Absence konsenzu se pak týká zásadní otázky: jaká autorita může džihád vyhlásit a zda taková autorita po smrti Proroka (632) či zrušení chalífátu (1924) existuje. Přitom se vyprofilovaly dvě protichůdné pozice. Zástupcem restriktivního pojetí je dlouholetý představitel pražských muslimů, podle kterého musí obranný džihád vyhlásit př́slušná náboženská autorita. Avšak dodává, že je dost dobře možné, že „v současné době v muslimských zemích 
žádná taková autorita neni“. Podobně dle staršího obchodníka musí džihád vyhlásit vládce, kterého uznávají všichni muslimové. Požaduje tedy širokou podporu dané autority: „Není možné, aby někdo odešel do džihádu a jiný zůstal sedět doma. "Ještě restriktivněji a jednoznačněji vyznívá postoj znalce sunny. Podle něj totiž nikoliv od doby zrušení chalífátu, ale hned od smrti Proroka Muhammada absentuje muslimská autorita nezpochybnitelně oprávněná vyhlašovat džihád:

„Jediné a nezpochybnitelné prǐklady džihádu jsou veškeré boje vedené islámským státem v době Proroka Muhammada. Všechno ostatní, co se poté nazývalo džihád, může být zpochybňováno. Potése totižnikdy nikdo neshodl na tom, $k$ do může džihád vyhlásit a zastavit. Pouze $v$ době prorokově to bylo jasné, protože toho vedl Bůh."

Znalec sunny tak konstatuje, že mezi muslimy panuje obecná shoda ohledně oprávněnosti džihádu za účelem obrany napadené muslimské země. Ovšem absence všemi muslimy uznávané autority vede $\mathrm{k}$ situacím, kdy jedna muslimská země napadne druhou, přičemž obě strany konfliktu tvrdí, že vedou obranný džihád. Což se logicky vylučuje. Na otázku, kdy se tedy může džihád vést, odpovídá: „No to já právě nevím. “ Argumentuje se tak podle našeho názoru podobně, jako vystupují současní muslimští kritici tvrdých trestů za cizoložství (ziná), kteří připouštějí, že islámské právo vysoké tresty sice stanovuje, avšak zároveň požaduje, aby takový přečin dosvědčili alespoň čtyři očití svědci. Což je v praxi téměř nemožné, čímž se dokládá distanc islámského práva od tvrdého trestání za cizoložství, přičemž má být vše ještě pojištěno hrozbou neméně tvrdých trestů za křivé svědectví a možností obhájení se obviněných pod př́ísahou (srov. Ostřanský 2014: 39). Podobně za absence shody na autoritě oprávněné vyhlašovat džihád sice nedochází k odmítnutí konceptu jako takového, ale k uznání jakéhosi moratoria na jeho praktikování.

Opačný názor tvrdí, že v současném světě autorita s právem vyhlašovat džihád existuje. Podle mladého konvertity a řady dalších může útočný i obranný džihád vyhlašovat hlava státu, at již jde o prezidenta, nebo krále: „V zásaděje dokonce jedno, zda je ten vládce spravedlivý, nebo nespravedlivý, hlavně musí být ručitelem pořádku na nějakém území. (...) A musí za sebou mít nějakou silovou složku. "Podmínkou je však podle informanta legitimní důvod pro vyhlášení džihádu: obrana muslimské společnosti nebo jejího spojence, a dokonce i situace, $\mathrm{kdy}$ „na našich bedrech leží mise seznámit sislámem celý svèt a dát každému člověku možnost vyjádřit se k islámu, přijmout ho, nebo neprìimout, volně, svobodně a bez nátlaku“. Pokud tedy podle informanta existuje režim bránící šíření boží zvěsti, může mu muslimská autorita vyhlásit válku: 
„A tato válka by byla džihádem, což si lze v dnešní době jen těžko představit, ale jako teoretická možnost to zůstává. " Např́klad mladší bývalý imám se zase domnívá, že obranný džihád nemusí být, na rozdíl od toho útočného, vyhlašován panovníkem nebo jinou autoritou, ale jedná se o individuální povinnost každého muslima: „Džihád, který se týká každého jedince, nepotřebuje, aby panovník nějak rozhodoval, to je obranný džihád."

Kromě toho informanti kladou důraz na množství detailních pravidel, za jakých lze válku vést, aby šlo o džihád. Podle mladšího konvertity jde třeba o dostatečný věk bojovníků, případně souhlas jejich rodičů. $Z$ dnešního pohledu se často jedná o restrikce bránící páchat válečné zločiny: nezabíjet civilisty, ženy a děti, ale také nepálit stromy a nevytahovat je z kořenů. Arabský inženýr či letitý představitel českých muslimů dále tvrdí, že džihád není nic, co by souviselo se zábavou nebo libou záležitostí. Jak uvádí tento dlouhodobý představitel českých muslimů: „Podle Koránu je válka věc, která je nemilá. (...) Boj prostě pro nás není žádný svatý. Boj je spravedlivý, nebo nespravedlivý. "Přitom se informant odvolává na následující koránský verš: „Bylo vám předepsáno, abyste bojovali proti zlu, $i$ když je vám to nemilé."

\section{Polemiky s útočným džihádem. Pluralitní interpretace historie}

Existuje tendence distancovat se od útočného džihádu s odkazem na to, že jde o něco zastaralého a přežilého. Druhý tábor však z různých důvodů připouští, že útočný džihád zůstává stále alespoň teoretickou možností. Například letitý představitel pražských muslimů odmítá útočný džihád, když popírá šiřrení islámu silou:

„Myslím si, že džihád bojem je už ve své podstatě možný pouze jako boj obranný. Pokud by se stalo, že nějaká muslimská země bude útočit na někoho, kdo ji neohrožuje, tak je to podle islámu zakázáno a nejedná se o džihád. Džihád nemůže být agrese a nemuiže být ani šírení víry násilím. Šírit víru násilím je proti Koránu a v rozporu sislámem."

Tento pražský muslim se přitom odkazuje na koránský princip zakazující donucování ve víře. Ten požaduje, aby měl člověk právo vybrat si víru svobodně. Víra přijatá pod tlakem je oproti tomu neupřímná, a tedy neplatná. Zde je zapotřebí připomenout, že je něco jiného šírit silou islámskou víru, tedy nutit nemuslimy ke konverzi, a něco jiného širrit silou islámskou politickou nadvládu neboli si podmaňovat jinověrce a činit z nich občany druhého řádu, tzv. chráněnce (dhimmî) disponující jistou nábožensko-právní autonomií (přitom pozice bezvěrců je ještě prekérnější). Jde tedy o něco jiného než rozšiřovat teritorium dar al-islám 
(př́bytek islámu spravovaný muslimskou vládou) na úkor dar al-harb (př́bytek války), k čemuž docházelo v prvních staletích islámu a i dnes k tomu vyzývají některá okrajová militantní hnutí. Právě historie se však stává dalším interpretačním bitevním polem v diskusi ohledně džihádu. Většinově se však informanti snaží historii reinterpretovat a neutralizovat tak, aby ukázali na neoprávněnost útočného džihádu.

Např́klad dlouholetý představitel českých muslimů připouští, že útočný džihád byl v minulosti oprávněně realizován, v dnešních podmínkách se však jedná o koncept zastaralý: „Maximálně, co bych mohl přijmout z toho jakoby útočného, jak vy ř́káte, to je podle mě stará verze, která dneska už nemusí být."V minulosti prý docházelo $\mathrm{k}$ tomu, že státní moc na různých místech světa bránila misijní činnosti muslimů: „Když byl někdo, kdo jim v tom bránil, tak armáda to prolomila. Takže z toho vychází tehdejší výklad. "Dnes však prý takové bariéry pro šíření Božího slova neexistují, a to ze dvou důvodů: celosvětovému rozmachu internetu a vysoké míře svobody projevu a vyznání, která je realitou především v Evropě. Výsledkem je prý „volný trh“, kde každý svobodně nabízí a nakupuje nejrůznější náboženské produkty, a každý si tak může vybrat, čemu věřit. Podobně se na realitu současného svobodného světa odvolává starší konvertita, když legitimní džihád omezuje na dobu Proroka Muhammada. Demokratickou politiku na Západě totiž chápe jako funkční alternativu násilí a teroru. Namísto kulek preferuje volební urny, když ř́ká: „Nejen ve Francii je spousta muslimů. Tak si spolu sedneme a zvolíme si zástupce, který půjde do parlamentu a bude lobbovat za zájmy muslimů na úrovni evropských zákonů."

Oproti tomu arabský inženýr jde cestou relativizace a bagatelizace role útočného džihádu v historii. Připomíná, že v těch nejlidnatějších muslimských zemích jako Indonésie a Malajsie² se islám nešíril vojenskou expanzí. V dalších př́ípadech se prý rozšírili, jako třeba v Andalusii, protože muslimové byli pozváni jako spravedliví vládci do vnitřně rozvrácených společností. Kromě toho se domnívá, že tam, kde se šíril silou, nešlo ani tak o útok, jako spíše o obranu. Islám je prý náboženstvím, kterého se velmoci počínaje mekkánskými Kurajšovci, Persií či Byzancí vždy obávaly, protože podemílá základy, na nichž stojí jejich ekonomická a politická moc. Proto velmoci proti muslimům vždy bojovaly. Oni se pak jen bránili, v boji vítězili a islám expandoval.

Názorové štěpení ale panuje i zde. Starší obchodník rozlišuje obranný (al-mudáfa) a útočný (at-talab) džihád, přičemž oba typy mohou být za jis-

2 Indonésie představuje skutečně nejlidnatější převážně muslimskou zemi, počet obyvatel překračuje 270 milionů. Malajsie je ovšem spíše středně velká země co do počtu obyvatel (32 milionů), náboženské složení je velmi pestré a muslimové zde představují zhruba dvě třetiny populace. 
tých podmínek legitimní. Jak ř́ká: „Když přišel neprítel, tak děláte džihád, aby nepř̀iši k vašemu městu. Chcete ho zastavit, bezpečnost. A pak se něco stalo, máte nèjaké právo a jdete, armáda jde na druhý. Kvůli spravedlnosti. "Mezi legitimní důvody pro vedení džihádu tak vedle obrany stanovuje i prosazování spravedlnosti, nikoliv ovšem touhu po kořisti či majetku. Podobně dle mladšího konvertity patří mezi tři legitimní důvody pro vyhlášení džihádu obrana vlastní společnosti, obrana spojence a útok na režim, který brání svobodnému šíření islámu. A pokračuje: „Z toho pak plyne, že některý džihád bude útočný, některý obranný. Pomoc spojenci nebo hypotetická možnost zákroku proti brutálnímu, tyranskému a hrubě utlačujícímu režimu by byl ten útočný. Hájení vlastního území pak obranný. "Konečně, mladší bývalý imám se od konceptu útočného džihádu též nedistancuje, ani ho nerelativizuje. Na rozdíl od většiny informantů ho ale pojímá jako součást běžné mezinárodní politiky. Mezistátní války totiž př́ležitostně vedou muslimské i nemuslimské země. A pokud jde o zemi muslimskou, její panovník tuto válku může prohlásit za džihád.

\section{Stopování plurality. Autorita, etika a čtení historicko-politické reality}

Starší konvertita reprezentuje muslima, který tvrdí, že islám ani džihád do hloubky nestuduje a studovat nehodlá. Drží se každodenní četby Koránu a hadísů a vůči jiným zdrojům je ostražitý: „fá to podrobně nezkoumám. Pro mě je džihád uživit rodinu. To je ten velký, skutečný džihád. Ale abych seděl a zkoumal názory učenců, na to fakt nemám čas. "K současným interpretačním disputacím pocituje jako praktik odpor a záměrně je ignoruje: „Neřešit teoretické otázky. Ten, kdo moc žvaní, v životě málo dělá. Je mi čtyřicet pèt let, nevím, kolik času mi ještě zbývá, ale nechci promarnit sviuj život nějakou utopickou teorií." Ne pro všechny informanty je tedy koncept džihádu tak důležitý, aby stál za podrobnou reflexi. Přesto všichni informanti svou interpretaci džihádu i její východiska - explicitně, či implicitně, záměrně, či mimoděk - nabídli. Jestliže tedy pozorujeme pluralitu až protichůdnost názorů týkajících se džihádu a jeho aplikace v současném světě, lze si položit otázku po příčinách této interpretační rozmanitosti.

Za prvé, jde o odkazování se na různé náboženské autority a jejich pojetí džihádu, nebo naopak hledání vlastní interpretace. Např́iklad letitý reprezentant českých muslimů reprezentuje tábor, který se nehlásí k žádné konkrétní autoritě, a svou cestu k porozumění džihádu popisuje takto: „fá se nerad hlásím k nějaké konkrétní právní škole. Ani ke konkrétní osobè. Protože jsou věci, které beru od jednoho učence, dalš̀ část zase beru od jiného. (...) Já jsem muslim, který se snaží hledat. "Znalec sunny se k žádnému z interpretů džihádu také nehlásí. $\mathrm{S}$ vědomím složitosti problematiky prý nedokáže rozsoudit, zda má některý 
z nich pravdu, př́padně který to je. Naopak druhý tábor své pojetí džihádu odvozuje od nějaké autority. Třeba arabský inženýr se hlásí ke globálnímu televiznímu kazateli Júsufu al-Qaradáwímu: „On je velmi mírný, $i$ kdyžje někdy ukazovánjinak. (...) A takjejeden z lidí, kterého názor v džihádu si vážím. "Podobně se vyjadřuje i mladší bývalý imám, podle něhož všechny čtyři právní školy vykládají džihád „víceméně stejne“ , ale vymezuje se proti súfijskému islámu, který se podle jeho názoru nachází mimo ortodoxii a koncept džihádu často popírá. Jako svého hrdinu, především džihádu jazykem, pak jmenuje Ahmada ibn Hanbala: „Za jeho života se objevila hereze. Tehdejš́ panovník Abbásovské ríše podlehl vlivu jedné sekty. (...) Vètšina učenců mu ze strachu přikyvovala. Tento muž ale řekl pravdu. (...) Byl mučen, bylo mu vyhrožováno smrtí. Ale préesto trval na tom, že řekne pravdu a nedovolí, aby byl islám zmènèn. "Starší bývalý imám pak zastává jakési střední stanovisko. Na jednu stranu hájí interpretační toleranci, otevřenost a flexibilitu. Na stranu druhou se hlásí k hanafijské právní škole a k duchovní autoritě v podobě úřadu vrchního muftího Bosny a Hercegoviny. Podobně se mladší konvertita hlásí k současnému bosenskému učenci Muhammadu Porčovi, jenž navazuje na reformistický salafismus a odsuzuje terorismus. Zároveň ale informant zdůrazňuje nutnost interpretovat islám pro potřeby dané doby: „Dané zdroje je zapotrebí brát s rezervou a následovat to, co je vhodné k následování. (...) Mazhab (právní škola, pozn. K. Č.) slouží člověku, ne člověk mazhabu."

Za druhé, pojetí džihádu souvisí s porozuměním islámské etice. Např́íklad starší bývalý imám nachází podstatu džihádu v ochraně života člověka, jeho víry, majetku, důstojnosti a potomků. $\mathrm{V}$ tom spatřuje „pět priorit, kolem kterých se toč́ veškeré intence islámského práva, a tím i islámského náboženstuí". Arabský inženýr se zase rozpomíná na etický princip, podle něhož by jednání lidí nemělo vést ke zhoršení stávajícího stavu: jednou z podmínek džihádu mečem tak je, že musí zabránit ještě většímu krveprolití. Lze se také setkat s etickým pravidlem hledání zlaté střední cesty mezi krajnostmi. Většina informantů však zdůrazňuje etický princip prosazování dobrého a bránění zavrženíhodnému. Tento imperativ však vykládají různě, což má různé implikace. Zde je zapotřebí upozornit, že dodržování etického imperativu na osobní rovině má odlišné důsledky než na rovině společenské. Snaha být lepším člověkem a bojovat se svými slabostmi je něco jiného než bránit zlu ve svém okolí a prosazovat v něm to, co subjektivně pokládám za dobro. Druhé pojetí je potenciálně konfliktní, střetávají-li se ve společnosti různé koncepty dobra a zla. Např́íklad letitý představitel pražských muslimů hovoří o aplikování principu na úrovni jednotlivce: „Každý správný muslim musí vykonávat džihád, aby se upevñoval v konání dobra a vyhýbal se špatnostem. "Oproti tomu dlouholetý představitel českých muslimů totéž neomezuje jen na úroveň jedince: „Džihád znamená vynaložit maximální úsilí. 
Bud'k dosažení něčeho, nebo k odvracení něčeho, tedy postavit se proti něčemu." Informant naznačuje, že jde o univerzální etický princip, se kterým se mohou ztotožnit i nemuslimové.

Za třetí, pojetí džihádu ovlivňuje interpretace historického kontextu, v němž byly relevantní koránské verše seslány a v němž první generace muslimů džihád praktikovaly. Historické souvislosti zrodu posvátných textů je proto podle staršího bývalého imáma pro interpretaci džihádu zapotřebí znát stejně dobře jako texty samotné: „Koránské verše mají svůj historický kontext a v tom smyslu jsou to často pouze vyprávèni o událostech, které se v konkrétni době děly. Takže nemusí každý text zmiňující se například o džihádu být nutně $i$ argumentem čili jakoukoliv oporou pro ledajaký názor. "V souvislosti s historickou kontextualizací výroků o džihádu obsažených v Koránu a prorocké tradici rozhovory prosvítá ostré dělení historie první generace muslimů na tzv. mekkánské a medínské období. Tato dichotomie pak u informantů ústí v rozdílné interpretace oprávněnosti násilí. V mekkánském období totiž byly sesílány verše nabádající $\mathrm{k}$ nenásilí a trpělivosti tvárí v tvář nepřátelství a agresi. Jak vysvětluje arabský inženýr: „Tèch proních třináct let, jak Muhammad žil mezi tèmi modloslužebníky nebo nevěrícími, tak oni dokonce i někteř́ z nich mučili muslimy (...), ale Bůh vždycky v těch proních trininácti letech zakazoval, aby bojovali, a řekljim, aby byli trpěliví. "Oproti tomu v medínském období se postoj Boha k násilí mění: „Tak po jeho odchodu pokračovali v tom, že chtěli je zlikvidovat. A v té chvíli Bůh dovolil, aby se bránili. "Informanti svou situaci v Česku často chápou jako analogii mekkánského období. Není proto náhodou, že zdůrazňují umírněné interpretace džihádu, kdy proti islamofobii staví trpělivost.

Za čtvrté, většina informantů různě explicitně reflektuje skutečnost, že nejde jen o interpretaci raných dějin islámu, etických principů nebo posvátných textů, ale stejně tak o interpretaci reality současného světa, ve kterém by se měl koncept džihádu aplikovat. Ve světě si proto čtou úplně stejně jako $\mathrm{v}$ textech. Jedno pak představuje kontext pro interpretaci druhého. Významy přisuzované konceptu džihádu i politickému dění v Evropě a především na Blízkém východě jsou výsledkem právě takovéto dvojí hermeneutiky. Explicitně to formuloval mladší konvertita, podle něhož má sice hlava státu právo vyhlásit džihád, ale to ještě neznamená, že je to její povinnost: „Závisí to na situaci. Máš možnost, ale balancuješ. Už je v tom ta politika. "Podobný problém se týká distinkce mezi obranným a útočným džihádem, který je dnes podle většiny informantů nelegitimní. V realitě je ale dle informanta obtížné jasně rozlišit útok od obrany. Proto mnohdy nelze rozhodnout, zda jde o džihád obranný, či útočný. Kupř́íladu př́činou válek prvních generací muslimů s Perskou a Byzantskou říśí byla skutečnost, že bránily šiřrení islámu a umučily přitom posly vyslané z Arábie, př́padně napadaly nemuslimské spojence muslimů, nebo se dokonce chystaly za- 
útočit na Islámský stát, takže obranou pak byl preventivní útok. Diskuse ohledně oprávněnosti džihádu se tedy netýká jen potenciálně konfliktní interpretace islámských textů, ale stejně tak politické reality. Podobně znalec sunny konstatuje, že sice mezi muslimy panuje shoda ohledně oprávněnosti džihádu za účelem obrany napadené muslimské země. Ovšem absence všemi muslimy uznávané autority vede $\mathrm{k}$ situacím, kdy jedna muslimská země napadne druhou, přičemž obě strany konfliktu tvrdí, že se brání a vedou legitimní obranný džihád. Což se vylučuje. Muslimové se tedy neshodnou na tom, jaká autorita je oprávněná vyhlašovat džihád, ale především na tom, zda taková autorita $\mathrm{v}$ dnešním světě vůbec existuje. Dále se v př́padě konkrétních konfliktů neshodnou ohledně toho, kdo je agresorem a kdo obětí, a má tedy právo na sebeobranný džihád.

Věcí konfliktní interpretace politické reality je pak také to, zda byly, nebo nebyly splněny další nutné podmínky pro vyhlášení džihádu: vyčerpání všech nenásilných možností řešení konfliktu; šance ve střetu vůbec zvítězit; proporcionalita sebeobranného násilí, které by mělo být úměrné násilí agresora; požadavek, aby výsledkem bojů nebylo více obětí, než by jich bylo, pokud by se $\mathrm{k}$ džihádu nepřistoupilo. Připouští-li část informantů legitimnost sebeobranného džihádu proti okupaci (Palestina) nebo diktatuře (Sýrie), opět se dostáváme na pole interpretace toho, zda se v daném př́padě skutečně jedná o okupaci, př́ípadně o neomluvitelně represivní diktaturu. Konečně, na pomyslný tenký led interpretace reality se dostáváme i ve věci interpretace toho, za jakých podmínek lze džihád vést: od obtížně ověřitelného požadavku, aby participace na bojových operacích válečníkům nepřinášela osobní potěšení, až po spor o to, kdo jsou $\mathrm{v}$ řadách nepřátelské skupiny bojovníci a kdo civilisté, kteř́ by se v džihádu neměli stávat terčem útoků.

Mezi informanty nepozorujeme čtení světa optikou tzv. kosmické války, tedy všeprostupujícího metafyzického konfliktu dobra a šírícího se zla, proti kterému by měl každý správný věřící v sebeobranném boji vystoupit. Nejobecnější motiv prolínající rozhovory je ale podobný, že totiž muslimové v Česku, Evropě i na Blízkém východě čelí tlaku; v lepším případě předsudkům a xenofobii ze strany majoritní společnosti, v prŕpadě horším vojenské okupaci a ze zahraničí podporovaným diktátorům. Tento alarmistický a až apokalyptický způsob čtení světa, ve kterém žijí, vytváří potenciálně prostor pro uplatnění sebeobranného džihádu. Jeho uvedení do praxe ovšem neutralizuje množství obtížně rozřešitelných podmínek souvisejících s interpretací sociálněpolitické reality spíše než posvátných textů, především požadavek, aby obranný džihád vyhlásila legitimní islámská autorita, která ale dnes dost možná neexistuje. Na druhou stranu lze i mezi informanty samými nalézt skeptický argument upozorňující na až 
př́liš volný vztah mezi interpretací islámské tradice, interpretací reality dnešního světa a jednáním implementujícím do praxe koncept džihádu. Na meze diskuse a argumentace upozornil např́iklad starší bývalý imám: lidé, pokud chtějí, si podle něj dokáží zdůvodnit či racionalizovat jako bohulibé jednání prakticky cokoliv.

Za páté, podle znalce sunny prochází džihád v posledních zhruba třech desetiletích reinterpretací díky dialogu muslimů se Západem. Podle informanta se nový interpretační trend zakládá na jediné prorocké tradici rozlišující velký a malý džihád a původně byl vyvolán snahou nabídnout Západu vlídnější tvář islámu. Není tedy podle našeho soudu divu, že se nový trend uchytil i v muslimské diaspoře v Česku s tradicí mezináboženského dialogu odstartovanou po roce 1989. Jakkoliv zůstává nezodpovězenou otázkou, nakolik jsou výroky informantů upř́mné a reflektují jejich autentické interpretace džihádu, a nakolik jsou vedeny pragmatickou snahou prezentovat islám v dobrém světle a majoritní společnosti tak nabídnout deformovanou verzi džihádu. Informanti totiž měli tendenci reagovat defenzivně, preventivně líčit islám jako mírumilovné náboženství a apologeticky oddělovat džihád od násilí, když spíše než na to, co džihád je, kladli důraz na to, co podle nich v žádném př́padě není. Bylo zřejmé, že jejich předporozumění situaci dotazování si je vědomo skutečnosti, že je většinová společnost vůči islámu nedůvěřivá a koncept džihádu rezonuje negativními konotacemi.

\section{Závěr}

Vykrystalizovala dvě základní pojetí džihádu, široké a úzké. Na jedné straně je džihád líčen jako široký koncept spjatý s bohulibým úsilím věřícího, přičemž je preventivně, a až defenzivně, oddělován od násilí. Druhé pojetí je úzké, zdůrazňující ozbrojený boj, jakkoliv vesměs obranného charakteru. Pojetí džihádu přitom u většiny informantů osciluje mezi oběma póly. Informanti dále nejevili př́lišného entuziasmu ve věci typologie různých forem džihádu, které jsou doménou islámské právní vědy a také západní akademické literatury zabývající se džihádem a variabilitou jeho pojetí (srov. Kropáček 2007; Mendel 2010). Jiní informanti se ale naopak hlásili hned k několika typologiím zároveň. Nakonec tak vykrystalizovaly tři odlišné typologie, jež je možné rozvíjet právě na půdorysu širokého pojetí džihádu: základní dichotomie malého a velkého džihádu, tedy takzvaný džihád srdcem a džihád mečem; podrobnější členění na džihád srdcem, jazykem, rukou (práce pro veřejné dobro) a mečem; sestupné členění na džihád rukou (fyzické zabránění zlu), jazykem (verbální odsouzení špatnosti) a srdcem (odmítnutí zla v srdci a modlitbou), jež je založeno na etickém principu prosazování ctnostného a bránění zavrženíhodnému. 
Pokud jde o úzké pojetí, tedy džihád mečem, informanti se shodují, že je př́pustný v sebeobraně. Naopak existuje tendence odmítat útočný džihád, zejména při šiření víry. Část informantů však možnost útočného džihádu připouští, jakkoliv argumentují rozdílně. Slabý konsenzus se týká také podmínek, za jakých lze obranný džihád vyhlásit a vést. Zejména nepanuje shoda na tom, jaká autorita může džihád vyhlašovat a zda taková autorita dnes vůbec existuje. Absence konsenzu se týká také toho, zda džihád mohou vést jen státní aktérii, nebo také ti nestátní. Podmnožinou této problematiky je pak také otázka, zda se jedná o kolektivní či individuální povinnost. Zatímco pak většina informantů vykazuje džihád do oblasti mezistátních vztahů, menšina ho chápe i jako odpor obyvatel proti cizí okupaci nebo nespravedlivé vládě, přičemž existuje i pojetí chápající ho jako sebeobranu v každodennosti.

Tato pluralitnost, protichůdnost a až konfliktnost jednotlivých interpretací islámu není sama o sobě překvapivá. Překvapivé je, že ji pozorujeme v prostř̌edí relativně úzkého organizačního jádra českých muslimů, kteří se shodně hlásí k sunnitské ortodoxii, a také to, že se týká konceptu nikoliv okrajového, ale vzhledem k mezinárodněpolitickému dění mezi českými muslimy po mnoho let diskutovaného, kdy by tedy šlo předpokládat jistou názorovou konvergenci. Proto bylo identifikováno pět možných faktorů ovlivňujících interpretační pluralitu džihádu a názorů na jeho př́padnou (ne) legitimní aplikaci v praxi: (1) vztahování se k různým duchovním autoritám a právním školám, které nabízejí různé interpretace džihádu, včetně možnosti takové autority odmítnout a spolehnout se na vlastní interpretaci islámských textů; (2) vztahování se k různým etickým principům jakožto interpretačním východiskům džihádu; (3) různost intepretace dějin prvních generací muslimů a kontextů, ve kterých docházelo k šírení islámu a ve kterých Bůh sesílal koránské verše; především důraz na rozlišování tzv. mekkánského a medínského období, přičemž současná situace muslimů v Česku je chápána jako analogická období mekkánskému, z čehož pak vyplývá tendence k trpělivému džihádu srdcem spíše než mečem; (4) různorodost až konfliktnost interpretací současné politické reality, jež sama slouží jako kontext pro interpretaci islámských textů a legitimní aplikace džihádu v praxi, přičemž se jako podstatná jeví absence konsenzu ohledně existence autority nadané legitimním právem vyhlašovat džihád nebo problematičnost v realitě rozřešit, kdo je agresorem a kdo napadeným, kdož by mohl sáhnout k sebeobrannému džihádu; (5) vztahování se k různým publikům, tedy vymezování se proti dezinterpretacím džihádu v pojetí islamofobů i islámských teroristů a související snaha apologeticky prezentovat islám většinové společnosti v pozitivním světle, což může spolu s mezi-náboženským dialogem vychylovat interpretaci džihádu směrem k nenásilnému pojetí - otázkou však zůstává, nakolik jsou tyto interpretace etablované a autentické. 
Vidíme tedy, že vztah mezi posvátnými texty, způsoby, jakými je muslimové interpretují, a nakonec i tím, co z toho vyvozují pro oblast jednání, není v souladu s tezí Maxima Rodinsona nijak jednoznačný a př́močarý. A to ani v př́padě českých muslimů z organizačního jádra - hlásících se $\mathrm{k}$ téže sunnitské ortodoxii, žijících ve stejné historické době a na území téhož státu. Jinými slovy, lze odmítnout představu muslima jako kyborga, jehož jednání je determinováno softwarem v podobě islámského náboženství (srov. Ostřanský 2016). V souladu s tezí Marka Juergensmeyera zase vidíme, že pojetí konceptu džihádu se vedle interpretace posvátných textů odvíjí i od interpretace reality světa, ve kterém řadoví muslimští interpreti žijí a v němž si čtou úplně stejně jako v textech samotných. Množství požadavků, jež islámské texty stanovují jako podmínky pro vyhlášení a následné vedení legitimního džihádu mečem, nevede k odmítnutí koránského konceptu, ale k určitému moratoriu na jeho implementaci do praxe. K tomuto moratoriu ovšem také přispívá až paralyzující neschopnost jednoznačně určit, zda jsou v realitě dané požadavky naplněny, či nikoliv. Namísto džihádu mečem proto muslimové kladou větší důraz na džihád srdcem, kde posvátné texty nestanovují množství podmínek pro jeho vedení, stejně jako tento koncept neústí do slepé interpretační uličky stran toho, zda jsou tyto podmínky v realitě naplněny. Dokonce lze na závěr stanovit analyzovanými rozhovory a Markem Juergensmeyerem inspirovanou otázku, zda interpretace reality nehraje při interpretaci konceptu džihádu, a především při interpretaci jeho vhodné implementace do praxe, větší roli než interpretace posvátných textů.

Duben 2021

\section{Literatura}

Abdel-Malek, Anouar. 1963. Orientalism in Crisis. Diogenes 11, 44: 103-140.

Arnason, Johann Páll. 2003. Civilizations in Dispute. Leiden: Brill.

Čejka, Marek. 2020. Korán, meč a volební urna. Zdroje a podoby islamismu. Praha: Academia.

Geertz, Clifford. 1968. Islam Observed. Religious Development in Morocco and Indonesia. Chicago: Chicago University Press.

Hendl, Jan. 2008. Kvalitationí yýzkum. Praha: Portál.

Hourani, Albert. 1976. History. In: Binder, Leonard (ed.): The Study of the Middle East: Research and Scholarship in the Humanities and the Social Sciences. New York: John Wiley and Sons: 104-125. 
Juergensmeyer, Mark. 2007. Teror v mysli boží. Praha: CDK.

Kepel, Gilles. 2002. Fihad: The Trail of Political Islam. Cambridge:

Harvard University Press.

Kepel, Gilles. 2008. Beyond Terror and Martyrdom: The Future of the Middle East. Cambridge: Belknap Press of Harvard University Press.

Kropáček, Luboš. 2007. Duchooní cesty islámu. Praha: Vyšehrad.

Kropáček, Luboš. 2012. Náboženské pole muslimských přistěhovaleckých komunit. In: Havelka, Miloš a kol.: Víra, kultura a společnost. Náboženské kultury v českých zemích 19. a 20. století. Červený Kostelec: Pavel Mervart: 127-146.

Kurzman, Charles. 2011. The Missing Martyrs: Why There are so few Muslim Terrorists. Oxford: Oxford University Press.

Mendel, Miloš a kol. 2008. Islám v srdci Evropy. Praha: Academia.

Mendel, Miloš. 2010. Džihád. Islámské koncepce šiření víry. Brno: Atlantis. Ostřanský, Bronislav. 2014. Atlas muslimských strašákủ. Praha: Academia.

Ostřanský, Bronislav. 2016. Islám a muslimové českými očima - dialog, nebo míjení? In: Beránek, Ondřej - Ostřanský, Bronislav (eds.): Stíny minaretů. Islám a muslimové jako předmèt českých veřejných polemik. Praha: Academia: 14-56.

Ostřanský, Bronislav (ed.). 2017. Islamofobie po česku. Praha: Vyšehrad. Pape, Robert. 2006. Dying to Win. Strategic Logic of Suicide Terrorism. Chicago: Chicago University Press.

Rodinson, Maxim. 2015. Marxism and the Muslim World. London: Zed Books.

Said, Edward W. 1981. Covering Islam. New York: Pantheon Books. Said, Edward W. 2006. Orientalismus. Západní koncepce islámu. Praha: Paseka.

Strauss, Anselm - Corbin, Juliet. 1999. Základy kvalitativního výzkumu. Brno: Podané ruce.

Topinka, Daniel (ed.). 2016. Muslimové v Česku. Etablování muslimů a islámu na veřejnosti. Brno: Barrister and Principal. 